\title{
REVELATIONS. THE WILD DUCK VERSUS HAMLET
}

\author{
Brînduşa Orăşanu ${ }^{22}$
}

\begin{abstract}
The present work compares two literary figures, imagining the internal conflict of each, in connection to a secret. In Hamlet's case (Hamlet by $W$. Shakespeare), it is a traumatic impossibility to reveal a secret that leads to his death, while for Gregers (H. Ibsen's The Wild Duck), the opposite occurs, his inability to keep a secret leads directly to the death of another character. In this work the secret is viewed as the conscious concealment of content, while the motives for keeping or disclosing it at any cost are unconscious.
\end{abstract}

Keywords: secret, truth, to say, internal conflict, conscious content, unconscious motive

\section{Hamlet, searching for the lost father}

Reading Shakespeare's Hamlet, one may question why the prince does not immediately fulfil his father's ghost's wishes and order, killing the new king Claudius, a criminal and a usurper, as revenge. Freud provided this answer: Hamlet stalls the action because of his own unconscious Oedipus complex, incestuous and patricide-tinted. Ella Sharpe underlines the unprocessed grief keeping Hamlet captive before turning him into the victim of the superego and self-destruction.

André Green detects, surprisingly, the philosophic side of the Ego ideal in Hamlet: "Initially, the Ego ideal consisted in becoming equal to his father according to heroic morals [to act]. I saw how the stoic morals [to bear] would 
counterbalance the first. Caught in this conflict, Hamlet adopts a third moral that of detachment, which no longer consists of bearing the burden in a stoic manner, but instead searching for death in order to avoid both suffering and taking action. [...]. But this option cannot spare him of desire: the desire to sleep, which, according to Freud, is the ultimate desire of the dream" (Green, 2003, pp. 129, my translation).

For a large portion of the play, Hamlet is searching for truth: are the Ghost's claims that the former king's death was no accident, but rather fratricide, a reflection of truth? Is the Ghost an angel (messenger of truth) or a demon (bringer of lies)? To put reality to the test, the scientist in Hamlet sets up the play within a play experiment, and Claudius' reaction confirms that the Ghost is an angel revealing the truth.

However, from this point a new version of the question "why doesn't Hamlet act?" emerges - why doesn't he reveal, directly, verbally, the secret he learnt and checked? Hamlet doesn't do and doesn't tell...

The importance of saying in the play is major. During the play within a play there are two theatrical moments: the first illustrates the regicide in the form of a pantomime, while the second focuses on the same episode, brought to life through words. Well - as Green observes - the brother-killing Uncle Claudius shows himself to be indifferent regarding the pantomime, yet when he sees and hears the retelling of his deeds he literally jumps and stops the spectacle from continuing.

The parricide (the term is used by Green as synonymous with "fratricide" and "regicide", a sign that he addresses the paternal symbolic function) is represented three times in Hamlet: in the account of the Ghost, in the pantomime, and in a theatre play (the play within a play). Why is the pantomime necessary (which does not say anything, it only shows), and why does it leave Claudius indifferent? A. Green wonders, noting that only the theatre says something to the conscience, because the representation comes to life through language, while the pantomime seems only an unchanged replica of the Ghost's story. According to him, the pantomime is the aphasic variant of theatre.

My hypothesis is that Hamletian procrastination refers to, along with all its motives and ramifications, not only to postponing doing, but also 180 
postponing saying. If this is so, then the secret also appears in the foreground, with its conflict between keeping and disclosing.

Green asks, rightfully so, why Shakespeare, who leaves nothing to chance, inserts the pantomime in the play within a play? The answer he proposes is inscribed in the Freudian vision, which it completes: it is about the unconscious Oedipal desires of the main character (2003, pp. 143-144).

As I stated on another occasion, no matter how we have psychoanalytically advanced in "hamletology", Freudian interpretation remains valid and perhaps central. It has remained so important that it can be recognized even in a contemporary theatre performance, where, at the end of the play, Hamlet and his mother, Gertrude, die next to each other, and the son, instead of taking her in his arms as a child, crossing his arm over her chest, wraps his arms around her from behind, like a bridegroom (Victor Ioan Frunză, Metropolis, 2017).

Why didn't Hamlet reveal the secret, even asking Horatio and the guards, who had seen the Ghost, to keep quiet? At first, we think that the prince intends to verify the truth. This is confirmed with the play within a play, but Hamlet continues to hesitate disclosing it. But to whom?

The question led me to think of the protagonist of the movie De ce eu? [Why me?] (Giurgiu, 2015), Cristian Panduru. This character is also looking for the truth, also a victim of lies, duplicity and manipulation. The character gave me the impression he was not just searching for truth, but also for someone to tell it to and, a vital necessity, who would believe him. ${ }^{23}$

Therefore, does Hamlet have anyone to say it to? Before going over the possibilities (eventual receptors of the secret), let's take note that the information received from old Hamlet, who became the Ghost, has a traumatic allure. The trauma is individual as the son learns his father was killed by his own brother, who thus takes the queen and the kingdom, and even his son, since he has the demands of a new father. The trauma is also collective, because we are dealing with a king and a crown. These are characteristics that are linked to the content of information: criminal, incestuous and perverse content.

There also seems to be a second traumatic element, related to the form of communication: the old Hamlet reveals himself to others, but only tells Hamlet his secret. He also asks the latter for vengeance.

\footnotetext{
${ }^{23} \mathrm{He}$ tries speaking of it, but is treated as "paranoid".
} 
Hamlet is alone. At the affective age of a teenager ${ }^{24}$, he embarks, I believe, not only on a search for the actions he promised (the procrastination analyzed by Freud), not only on the exploration of the inner mystery, but also on the search for a lost father, a father he could tell and who would believe him.

It is said a lie is easier to believe the further from the truth it strays. The logic of this saying could be that it is difficult for us to identify with the perverse subject, author of the lie. ${ }^{25}$ We can formulate and reciprocate, namely that a truth is all the more difficult to believe the 'truer' it is, the explanation being linked to the traumatic character of the truths 'too' true in the sense of the lack of psychic protection, of the impossibility of psychic self-treatment facing the external stimulus. When we say that trauma is actually internal, we mean that the external stimulus collides with an already traumatic mental content, or we refer to a traumatic après-coup effect (Freud).

So Hamlet is looking for a father to speak to. Following Lacan, with his theory of paternal metaphor, A. Green was among the first psychoanalysts to point out that tertiarity, this logical concept, even if not founded on language, even if not reduced to language, finds in language one of its fields of application" ${ }^{26}$. The verbal communication of an experience "introduces the potential presence of the father, not by an explicit reference to this father, but by the mere introduction of a third element in this communicative duality" (Green, 1990, pp. 91, my translation). Thus, the so-called primitive communication, between mother and child or analyst and analysand, through the means of language, rises to a level of sophistication that allows another understanding of psychic labor (Green, 2005, pp. 679). Freud had already differentiated between thing-presentation, pertaining to the unconscious, and word-presentation, pertaining to the preconscious-conscious.

The paternal function is an abstraction. Delourmel (2013) even writes about a paternal principle), it is not the same as the real father, but the latter represents it. The tertiality embodied by the presence of a third party "appears implicated in any human experience that truly takes into account the existence

\footnotetext{
${ }^{24}$ Biologically speaking, throughout the plot, Hamlet's age starts at 18 and ends at 30, according to M. Harris Williams (1988).

${ }^{25}$ The extreme of this phenomenon is the "thief who cries "thief"" situation, which turns reality around. ${ }^{26}$ Green relied on Benveniste's linguistic reflection on the role of the third person in language (Her, Him). (Green, 2005, pp. 677-682).

182
} 
of the other in one's freedom to be and to become" (Balier, 2005, pp. 707). Balier stresses the importance of the notion of encounter, citing A. Green: the subject constitutes the other as part of a founding experience of the subject, and the other can only be encountered by listening to a speech that returns unto itself, after its reverberation over another subject (Green, 2002). On the other hand, the secret is evidently connected to the presence of the other.

Hamlet can truly represent the scene of the former king's murder; however, he seems unable of psychically elaborating this secret, which is what makes it a traumatic secret. Furthermore, in Freud's works, the notion of trauma evolved to the point of being considered "less related to an external or internal event, but rather to the absence of the possibility of elaborating certain sufferings belonging to psychic growth" (Botella, 2005, pp. 727).

Donald Meltzer (2008) differentiates between secret and mystery. We can consider that, while mystery supposes a process of internal and external exploration accompanied by the symbolic function, the secret, in our view of it in regards to the two plays, Hamlet and The Wild Duck, is an outlined element, with a conscious content subject to the conflict of being or not being told or shown.

Let us return to Hamlet's difficulty, not in showing it but in telling it (so much so that it is not related to an experience he directly lived, but an experience recounted).

Who could be the father, representing the paternal function, who hears, believes, names and qualifies the secret as truth - here in the most usual sense, of objective external reality, capable of being shared by the subject and the paternal object (according to the concept of objectivity through triangulation, proposed by Marcia Cavell)?

The old king is the first to be excluded. Not only is he the shadow of paternal function, he is also the primary source of the secret, who he passes on to his son to be not said, not thought, but acted upon. From the very beginning, the communicated content is full of violence.

Horatio? He is a presence that listens and believes, but he is part of the same generation, like a brother or imaginary friend, without the capacity to qualify. 
Gertrude or Ophelia? Excluded, not only because they are under the social conditions imposed on women at the time, but also because they either generally deny Hamlet's affects (the first) or because they do not have conservative strength and are duplicitous messengers of others' affects (the second).

Claudius? Excluded, being the one accused in the secret. It is worth mentioning he seems to most resemble a father, but that he is more like the father of the primal horde, incestuous, from the Freudian social theory.

Polonius, Rosencrantz or Guildenstern? Excluded: they are extensions of Claudius' perversity. Laertes? An honest "brother" and nothing more.

The only character showing some promise in embodying the paternal function is the king who follows, the third one: Fortinbras, who comes to finally deliver the symbolic order. Unfortunately, he arrives too late, as it is too late for Hamlet who, from the perspective of his secret, died because he kept it, and he kept it because he didn't find it a father.

\section{Gregers and the fight for the (so-called?) truth}

I will now move on to the other literary "clinic": the play of Norwegian writer Henrik Ibsen, The Wild Duck (1884), a play that expresses, it is said, one of the author's favorite themes, the conflict between lie and truth, or between false and authentic.

André Suares writes: "Out of all poets, Ibsen is the only dreamer, after Shakespeare [...]. Ibsen is fit for the Greek [...], because he is searching for the light in the darkest shadows [....] Passionate ideas [...]. He throws them one against the other; and almost always condemns the most noble and pure one. He crushes it in loving it" (1935, pp. 81-84). A contradictory position, to love truth and condemn it...

But let's first see, in short, what the plot of this play is, since it is likely lesser known. Gregers returns to his father's house, old Werle, where he finds out his long-time friend Hjalmar had married Gina, formerly housekeeper for Gregers' parents, that he has a house and a photo studio, all these with Werle's support. Remembering his mother had passed away with the painful 
conviction her husband was having an affair with Gina, Gregers thinks his friend Hjalmar built his marriage on a lie.

The rest of the play unfolds in the Ekdal household: Hjalmar, Gina, old Ekdal - Hjalmar's father - who works for Werle, and the daughter of the first two, 14 years old Hedvig, who is about to lose her sight because of a hereditary condition. In the attic, the family is housing a wild duck that Werke wounded and the Ekdals saved. The duck lives in captivity. It will never fly again. Hjalmar secretly loathes the duck. The family makes do day-by-day.

Gregers plans on renting a room in the Ekdals' house, because he doesn't want to live with his father. He begins to be preoccupied with the issue of truth concerning the past relationship between Werle and Gina, and increasingly convinced Hjalmar must find out this truth, for his and the family's sake. He tells Hjalmar.

A letter arrives in which Werle says he'd offer old Ekdal a monthly allowance so that, after the elder's death, the money would become an annuity for young Hedvig. The news makes Hjalmar connect the girl's impending blindness to Werle's similar condition, and to angrily realise that Hedvig could be Werle's child. He leaves the home.

Gregers sees the girl is desperate and convinces her that, if she kills the wild duck, this sacrifice would prove how much she loves her father and he would return. The second day, Hedvig commits suicide.

The play ends with the argument between Gregers and the Ekdal family friend, Dr. Relling. Gregers insists the girl's death was not in vain and that Hjalmar will find his peace in life (with her love in his heart, as is implied). On the contrary, Relling claims the effect will be short-lived and in one year Hjalmar will return to his old habits.

(Before continuing, I confess that, initially, I intended to rename the characters according to their familial relationship, thinking I would simplify and avoid Norwegian names that may be difficult to remember by someone who has not had time to see and pay the necessary attention to the play. I had begun with this plan that supposed splitting between two families, each with their own fathers, mothers, sons and daughter, grandfather. However, I was soon confronted with a dilemma - does Hjalmar fit better in the father category or in the son one? Meaning does his relationship with his daughter 
better define him or is the one with his father more important? The same goes for Hedvig - is she more of a daughter, a niece, or (after the full disclosure of the secret), a sister? I was perhaps under the illusion that a sociologic simplification was possible, but psychoanalytical thinking won, with its logic linked with unconscious conflicts and après-coup phenomena: the ulterior reveal of the secret modifies the meaning and significance of previous events. I gave up on the family scheme and stuck with the characters' names, as steadfast markers.)

Romanian theatre critics noticed that the actor who plays Gregers ${ }^{27}$ in Romania (Kerek, 2019) plays his part so well that we dislike him from the start. However, foreign literary critics likened Gregers to Hamlet, for the simple reason he is concerned with the issue of truth. In my opinion, their common aspect consists more in how they approached a secret, in a context we can call Oedipal. Gregers seems more of an antihero. You almost need to make an effort to acknowledge him as a main character, which makes it difficult to identify with him and to understand him, an unusual thing for someone who is donning the heroic mantle of truth.

In his correspondence with James Putnam, Freud stated something that could be considered his ideal: "The great ethical element in a work is truth and again truth and this should suffice for most people. Courage and truth are of what they are mostly deficient" (Freud, Letter dated March $30^{\text {th }}$ 1914, pp. 200).

Gregers seems to have both elements of the Freudian ideal, or Hamlet's ideal, but he wields them in a particular manner. Gregers' mother had passed away many years ago, when she had shown her son the pain Werle's betrayal had caused her. On one hand, this drove him away from home and made him refuse all that came from his wealthy father.

On the other, presently visiting his friend, history takes up its course with another dose of truth: he realizes the old maid is the current wife of his friend, then, shortly after, the 14 years old girl of the Ekdals is the result of his father's betrayal.

The word "sister" doesn't appear in the play, it is avoided, perhaps in the same way the concept of "fraternal transference" is avoided in psychoanalysis. Only the word "child" is featured in the play, a child who loves her father (Hjalmar), with a passion that grows the more he ignores her. We begin to

\footnotetext{
${ }^{27}$ The actor is Şerban Pavlu, in the play enacted at Bulandra theatre, directed by Peter Kerek (2019). 186
} 
see the fraternal relationship as the central significant, the wild duck, appears in dialogues.

In psychoanalytic theory and practice, the fraternal figure and fraternal transference are rarely approached, and, when remarked, seem to be considered more as defences against acknowledging parental transference. It is possible that transmitting these avoidances throughout the history of psychoanalysis began with the fact that Freud discovered the rule of free association while treating Emmy von N (using the method of suggestion)..., a patient who came with a fraternal phantasm of a traumatic allure. This would have led to the very seed of the free association dissymmetry of psychoanalytic method to be impregnated with such a fraternal phantasm, and also the avoidance, in the analyst, of a regression towards the "prehistoric" treatment by suggestion (Orăşanu, 2015).

Some authors, remarking in the Freudian commentary on Hamlet the lapsus that replaces Polonius' name with that of Laertes, see in this lapsus a disguised expression of the desire for fratricide, and deduce a motive that would have prevented Freud from paying the right attention to the preOedipal period in theory.

Before sharing with $W$. Fliess his discovery concerning the Oedipus complex (in a letter dated October 15 th 1897), Freud wrote him about the impact the death of one of his brothers, Julius, when the latter was 8 months old and the former 19 months old, had on him: ,(I know that)... I greeted my one-year-younger brother (who died after a few months) with adverse wishes and genuine childish jealousy and that his death left the germ of (self) reproaches in me. I have also long known the companion of my misdeeds between the ages of one and two years; it is my nephew, a year older than myself (...) The two of us seem occasionally to have behaved in a cruel fashion to my niece, who was a year younger. This nephew and this younger brother have determined what is neurotic, but also what is intense, in all my friendships" (Freud, 1897, pp. 194).

Therefore, according to my perspective, in psychoanalysis, the fraternal figure is already associated, on a subterranean level, with violence, which makes the analyst, in order to perceive and think it, have to pay it special attention.

It is what A. Green does with Hamlet where, outside of the fraternal relationship between the former king and Claudius, he imagines a sort of 
"prehistory" of the play, according to which Hamlet may have, on one hand, been the son of uncle Claudius and Gertrude, and on the other, the halfsibling of Laertes and Ophelia, Polonius' children. The prehistory Green imagined adds more fraternal violence, more resentment, more unsaid betrayals... Green states: "what is the function of the unsaid? Repressed by the author, it would go on to become the machine of the work, its silent motor, its hidden demon that will lead to the structuring of the manifest intrigue [...] Shakespeare will use this unsaid as an unconscious operator, an object of permanent counter-investment that forces tragedy to weave in order to cover it" (Green, 2003, pp. 270, my translation and underlining).

Let's return to The Wild Duck. Gregers fights for truth, but not for all truth. He militates for saying as long as it is limited to the Oedipal truth with its incestuous primal scene, in which he insists on drawing Hjalmar, telling him that his wife Gina had also been with old protector Werle.

However, a new truth appears on stage, unpredicted by Gregers' heroic plan: he has a half-sister on his father's side, Hedvig.

In Ibsen's play, the metaphor of the wild duck offers many characters the possibility of identification. It is a wounded bird, which will never be able to fly again, and because of this it refuses to live or, in Gregers' words, it refuses to "truly" live. We are dealing with a narcissistic wound, then with a suicide phantasy.

Once the entire secret is out - Hedvig is Werle and Gina's daughter this metaphor is crystallised around Hedvig. She tells Gregers:

“Hedvig: - Perhaps I'm not really my father's child.

Gregers (uneasy): - How could that be?

Hedvig: - Mother might have found me. And perhaps father has just got to know it; I've read of such things.

Gregers: - Well, but if it were so...

Hedvig: - I think he might be just as fond of me for all that. Yes, fonder almost. We got the wild duck in a present, you know, and I love it so dearly all the same" (Ibsen, 1884, p. 203).

From this moment on, apparently entirely disconnected from his own desires, Gregers begins to go from the insistence for telling the truth to insisting 188 
on action: the girl must kill what she holds dearest, meaning the wild duck, to prove to her father how much she loves him. We almost believe Gregers - after all, why wouldn't his intentions be good? - if only he wouldn't have added the following after convincing the girl: "But not a word to your mother about it!'”(Ibsen, p. 207, my italics).

This unexpected demand for secrecy, issued by an advocate of disclosure, settles the fraternal hatred Gregers feels for Hedvig, because keeping a secret from Gina, related to the killing of the wild duck, is the same as preventively removing the person who would have protected the child - her mother - from the stage.

Already through his insistence on revealing to Hjalmar the truth that will "liberate" his family, Gregers shows himself to be a candidate for the following interpretation: once returned home from auto-imposed isolation, he falls into his own history and learns that someone akin to a brother, Hjalmar, stole the paternal care he had himself renounced. We know that giving up is not automatically equal to accepting. Gregers moves with the Ekdals, Hjalmar leaves the Ekdals. The truth of the first banishes the second. In après-coup, we can think so: this truth was one marked by jealousy.

Then Gregers feels it is not enough to liberate his symbolic brother - in fact liberate himself from the latter. He must also free his biological sister - in fact free himself from her - and this seems to be an emergency (a similarly destructive urgency emerges towards the end of Hamlet, but it is more selfdestructive). While Gina makes efforts to convince her husband, who she knows very well, efforts that seem to work, Gregers goes forward with the sacrifice of the wild duck, a crucial moment when truth is flipped, transforming into an ideal in itself, into a purpose, into a perverse machine. Gregers' truth is marked by fraternal violence and is a support for fratricide.

Therefore, the final controversy between Gregers and Dr. Relling, between the ideal of telling the truth at any cost and the ideal of "the lie of life", of the illusion that softens life and makes it bearable, is a false polemic, and Relling knows this and shows that he is not taking the discussion too seriously. This is why Ibsen condemns the truth in the play, because it is not about the truth. 
André Gide comments on another piece by Ibsen, but the commentary is appropriate, as it is also about revealing the secrets of the past: "[...] But one must be careful not to make too much of the element of scandal. It is by pushing things rather than by colliding with them that one sets them in motion. We must always take into account the inertia of both souls and bodies. By colliding one often breaks, and that's the end. One must stir rather" (Gide, 1893, pp. 26).

I have approached the relation between cynicism and truth before (Orăşanu, 2012) and I have considered cynicism as a "false truth", because, on one hand, it glorifies the animal character of man and the lack of shame, therefore also hypocrisy, and, on the other hand, it presents an element of reality as being the whole reality, through a defensive mechanism against any kind of spatial or temporal ambiguity. Thus, cynicism - for example, through the raw, unmediated, anti-metaphoric verbal communication of a truth in contrast to the context of communication - avoids confronting the subject with separation anxiety, by imposing a spatial hyper-limit, and avoids the mourning process by imposing a hyper-temporal limit that cancels historicity. At the extreme, it can be about overinvesting the boundary between life and death. To the extent that it is a cruel variant of narcissistic perversion, cynicism needs the other to obtain this categorical limit.

Thus, in Gregers there is a denial of a possible meaning that would refer to the father figure and to the temporal continuity with the father, although he makes such an attempt, through his appearance at home.

Should we extrapolate the situation to the psychoanalytic clinic, the problem of the effect that the analysand has on the analyst arises, but also that of the effect of the analyst's interpretations on the analysand. Indirectly, Freud referred to the possibility of an analyst's thinking and expression, which we could call cynical, when he wrote about "wild psychoanalysis". Here is also where we see how the way in which its technical error may consist in the limited, reductionist perception of the patient's psychosexuality, excluding its meaning related to tenderness, and in the absence of tact and caution, that is, in not taking into account the effects interpretation has on the patient (Orăşanu, 2012). Freud underlined that interpretation is not informing the 
patient about himself, which explains why interpretations cannot be taken from books (Freud, 1910).

\section{Conclusions}

Psychoanalysis is particularly interested in internal conflict. In Hamlet, using the main perspectives offered by Freud and then by Ella Sharpe, we have a handy inference about the hero's inner struggle. The fight is led between, on one hand, his unconscious oedipal identification with the father's fratricidal rival (the source of procrastination, that is, delaying the promised action, to avenge the murdered father) and, on the other, the mourning that he is trying to process and that fills him with a self-destructive guilt that leads in an opposite direction than that of procrastination, to an emergency.

With Gregers, we have to deal with certain symmetries regarding Hamlet. His mother died, not his father. Oedipal betrayal comes from the father, not the mother. He did not process his mourning either, although 15 years have passed. Unlike Hamlet, Gregers almost forcibly enters the "new" family, Ekdal, where he discovers a sister. Can we infer some internal conflict in Gregers too? We could imagine one: between the desire for autonomy, both towards his father and his past, and the contrary desire to sink into the past to restore his childhood family to a "purified" form, devoid of falsehood. However, this conflict is severely unbalanced by the wild duck - a metaphor for intolerable de-idealization, which pushes Gregers away from the heroic problematic of truth and toward a (transient?) sector of cynical, perverse narcissistic functioning.

Werle the father had ordered that the wild duck be shot dead, and should we re-examine this, in the après-coup, he seemed to want to escape the living evidence of betrayal, to keep the secret, so, in Gregers' acceptance, to keep the lie. The Ekdals adopted the wild duck and offered it a life, supported by the "lie of life". Gregers, surely out of fraternal jealousy, invented the miraculous solution of killing what we might call "the sister's sister", completely forgetting his concern for the truth, and putting the opposite of his ideal into action, something that his father had tried but failed to do: the 
destruction of the girl and, with her, the burial of the secret.

We cannot exaggerate so much as to say that secrecy can be a cause of tragedy. However, we can find a difference between the two young men regarding its management. If in the case of Hamlet, the traumatic impossibility of telling the secret contributed to his death, in Gregers' case we have the opposite effect, as the inability to keep the secret directly led to the death of another.

We have addressed here the current meaning of the secret, that of specific, net content, which Donald Meltzer (2008) differentiates from that of the mystery, which we conceive rather as an exploratory process. Didier Lauru (2008) states that a "secret is made to be kept, but also to be shared through communication. It therefore excludes at least one person who does not have to know anything about the content of the secret, remaining excluded. [...] But for the keepers of the secret, the task is difficult. The burden of guilt and the knowledge of the secret can be fraught with consequences for the one who knows and for his descendants" (p. 98).

Let us also think, for example, about the frequent issue of adoptions...

The conclusion that derives from the comparison of the two heroes, with secrets leading to such different ends, is that, like the truth, the conscious concealment of secrets (the meaning approached in this work) has an individual and collective history that offers a specific context, and this context fully participates in the fate, pathogenic or sanogenic, dramatic or tragic, of the disclosure, the reveal. It should be noted that the reasons for keeping a secret at any cost or for the disclosure of a secret at any cost are unconscious. 


\section{REFERENCES}

BALIER, C. (2005). La tiercéité à l'épreuve de la criminologie [Criminology-proof tertiaryity], Rev Fr Psychanal, 3, pp. 703-716.

BOTELLA, S. (2005). L'oedipe du ça ou Edipe sans complexe [The Oedipus of that or Oedipus without complex], Rev Fr Psychanal, 3, pp. 717-732.

DELOURMEL, C. (2013). De la fonction du père au principe paternal [From the function of the father to the paternal principle], Rev Fr Psychanal, 5, pp. 775-1281.

FREUD, S. (1897). Naissance de la psychoanalyse [The birth of psychoanalysis]. Presse Universitaire de France, Paris, 1956.

FREUD, S. (1909-1916). L'introduction de la psychanalyse aux Etats-Unis [Introduction of psychoanalysis in the United States]. Gallimard, Paris, 1978.

FREUD, S. (1910). Despre psihanaliza sălbatică $[$ On wild psychoanalysis]. In Works (vol. 11).

Trei Publishing House, Bucharest, 2004, pp. 67-75.

FRUNZĂ, V. I. (Director). (2017). Hamlet [Play]. Bucharest: Metropolis Theatre.

GIDE, A. (1893). Journal (July 1893). In Journal, Univers, Bucharest, 1970.

GIURGIU, O. (Producer) \& Giurgiu, T. (Director). (2015). De ce eu ? [Why me? - Film]. Libra Film, România.

GREEN, A. (1990). La folie privée [Private madness]. Gallimard, Paris.

GREEN, A. (2002). La pensée clinique [Clinical thinking]. Odile Jacob, Paris.

GREEN, A. (2003). Hamlet and Hamlet. Bayard, Paris.

GREEN, A. (2005). Adieu à Deauville [Goodbye to Deauville], Rev Fr Psychanal, 3:677-682. 
HARRIS WILLIAMS, M. (1988). The Undiscovered Country: The Shape of the Aesthetic

Conflict in Hamlet. In Meltzer, D. \& Harris Williams, M. The Apprehension of Beauty. Karnac, London, 2008, pp. 84-133.

KEREK, P. (Director). (2019). Raţa Sălbatică [The Wild Duck - Play]. Bucharest: Bulandra Theatre.

IBSEN, H. (1884). The Wild Duck. The Walter Scott Publishing, London, 1905.

LAURU, D. (2008). Le secret des origines [The secret of origins]. In Enfances \& Psy [Childhood and Psychoanalysis], 2:97-105.

ORĂŞANU, B. (2012). Le cynisme, messager hâtif de Thanatos [Cynicism, the messenger of Thanatos], Rev Belge Psychanal, 74/2019, pp. 69-87.

ORĂŞANU, B. (2015). Complexe fraternel et dissymétrie. Emmy von N...[Fraternal complex and dissymmetry. Emmy von N], Rev Belge Psychanal, 72/2018, pp. 85-101.

SHAKESPEARE, W. (1600-1601). Hamlet, Prince of Denmark, The Complete Works (vol. V, pp. 326-495), translated by Leon Leviţchi and Dan Duţescu. Univers, Bucharest, 1986,

SUARES, A. (1913). Trois hommes: Pascal, Ibsen, Dostö̈evski [Three men: Pascal, Ibsen, Dostoïevski]. Gallimard, Paris. 